\title{
A CRITIQUE OF THE SOUTH AFRICAN NATIONAL LIFE-SKILLS AND HIV/AIDS SCHOOL POLICY: LESSONS FOR POLICY ADJUSTMENT
}

\section{T Raniga}

\section{INTRODUCTION}

South Africa has the fastest growing epidemic in the world with an estimated 1600 new infections occurring daily. According to the annual antenatal HIV sero-prevalence survey in 1994 the level of HIV infection amongst pregnant adolescents younger than 20 years was $6.47 \%$ rising to $12.7 \%$ in 1997 and $21 \%$ in 1998, with an increase of 65\% in the last year (Department of Health, 2001). To date of the more than 5 million people in the country that are living with HIV, more than half are young people aged 15-24 (Abdool Karim \& Abdool Karim, 2005). The social and economic implications of the epidemic on the educational and welfare sector of the country are undoubtedly serious and real.

Consequently, Van Rensburg, Friedman, Ngwena, Pelser, Steyn, Booysen and Adendorff (2002) poignantly contend that with the current maturation of the HIV/AIDS epidemic, responses to its psycho-social and economic implications are increasingly becoming dominant features in social policies. Badcock-Walters (cited from Gow \& Desmond, 2002) indicated that school-going children are bearing the brunt of the epidemic at the household level as it reduces their access to education, due to economic hardship and family care. The effects of such personal trauma associated with grief, stress and added family responsibilities on school-going children are serious. These trends are imposing "new" demands on state health, welfare and education provision, so much so that there is a need to monitor and evaluate policies and programmes that are being developed in order to meet these needs.

Bearing the above deliberations in mind, this paper presents the empirical findings of phase one of a larger study which comprised a quantitative audit undertaken in 74 secondary schools in the eThekwini region. The study's core purpose was to investigate the extent to which schools were aware of the National HIV/AIDS School Policy (Department of Education, 1999). One of the findings of a preliminary study that was conducted in 2001 was that a gap existed in the school system regarding the awareness of the Policy and the implementation of the Policy (Sewpaul \& Raniga, 2005). Following from this finding, the second objective of this study was to investigate the extent to which the National HIV/AIDS School Policy and the Life-skills, HIV/AIDS education programme (which is a tangible outcome of the Policy) was implemented in these schools. The third key objective was to examine the institutional capacities (time, human resource, finance and expertise) that existed in these schools to implement the Policy and the Life-skills, HIV/AIDS education programmes.

The paper is divided into two sections. Section one begins with an overview and appraisal of the National HIV/AIDS School Policy (Department of Education, 1999). Section two follows with a discussion of four key themes that emerged from the findings of the study:

- the extent of awareness of the HIV/AIDS School-based Policy;

- the challenges experienced by schools in the implementation of the National HIV/AIDS School Policy; 
- the lack of institutional capacity at school level to deal with the problem of HIV/AIDS (Khoza, 2002; Sathiparsad \& Taylor, 2005; Sewpaul \& Raniga, 2005);

- the disparity that exists between the institutional capacity of urban schools as compared to rural schools with regard to the implementation of the National HIV/AIDS Schools Policy and the life-skills, HIV/AIDS education programme.

\section{RESEARCH METHODOLOGY}

For the component of the study reported in this paper, structured interview schedules were administered to principals from 74 selected secondary schools in the eThekwini region of KwaZulu-Natal in South Africa. Marlow (1998:163) stated that structured interviews can be thought of as verbally administered questionnaires. Following Terre Blanche and Durrheim's (1999) steps in questionnaire construction, the structured interview schedule contained mainly closed ended questions and some open ended questions. Advantages of personally administering the interview schedule were of clarifying misunderstandings and securing a response rate of $100 \%$.

Probability sampling was used to allow each element in the population a chance of selection. A systematic random sampling method was used. The sampling frame consisted of a list of 370 secondary schools in the eThekwini region of KwaZulu-Natal in South Africa. The comprehensive list of secondary schools was structured in terms of district, circuit and ward. The intended size of the sample for the study was $20 \%$ of the total sampling frame, which equals to 74 . Every fifth school was selected from the list for this study. The data was coded, sorted and captured using SPSS statistical package version 11.0.

In contemporary South Africa, the classification of the country into urban and rural areas is a contentious one. For the purposes of this study, schools have been classified into urban formal, urban informal and rural. Taylor, Dlamini, Kagoro, Jinabhai, Sathiparsad and De Vries' (2002) definition of rural schools seemed most appropriate for this study. She stated that most rural schools in KwaZulu-Natal are considered under-resourced and poorly equipped as they lack basic services such as electricity, water, access to health services. Statistics South Africa (1998) defines an urban area as a settlement which has been legally proclaimed as urban. Additionally the geographic locality of an urban settlement is categorized into urban formal and urban informal (Statistics South Africa, 2003). For the purposes of this study urban formal schools are considered well-resourced and well equipped with access to social services, such as health, welfare, housing, water, roads, electricity and recreation.

Simpson (2001) noted in her study on social work in informal settlements that informal settlements are characterized by a lack of adequate electricity, water, refuse removal, sanitation and recreational facilities. Following from this, the researcher defines schools located in the urban informal areas as generally under-resourced and poorly equipped.

\section{SECTION ONE: AN OVERVIEW AND APPRAISAL OF THE SOUTH AFRICAN NATIONAL HIV/AIDS SCHOOL POLICY}

Young people are themselves extremely susceptible to contracting the virus as a result of their subordinate socio-economic status and because of their susceptibility to experiment with drugs and alcohol during the adolescent phase of life, and their lack of access to detailed and accurate HIV information and prevention services. In South Africa young people aged 20-24 constitute 44\% of the national population and socio-structural factors such as high unemployment rates, poverty and violence have increased their vulnerability to HIV (Harrison, 2005). Thus, the extent to which 
their rights are protected and the services and information they receive can help determine the quality of life of millions of young people.

As an acknowledgement of the social and economic implications of the HIV/AIDS epidemic on youth, and that young people are the key to controlling the epidemic the ex-Minister of Education, Professor Kader Asmal, published in Government Gazette, Notice 1926 of 1999 the National Policy on HIV/AIDS, for learners and educators in public schools, and students and educators in further education and training institutions (Department of Education, 1999).

The National HIV/AIDS School Policy (hereafter referred to as Policy) has good intentions to provide broad guidelines for the implementation of HIV/AIDS programmes in the school context and hopes to make a positive difference to learners, students and educators. The Policy is consistent with the National Education Policy Act, 1996 (No. 27 of 1996) the Constitution of South Africa (1996) and the Trisanso plan (Department of Education, 2000a, 2000b, 2000c). The Policy (Department of Education, 1999) focuses on three key areas: HIV/AIDS-related discrimination and stigma, maintaining a safe school environment and HIV/AIDS and sexuality education. Compulsory HIV testing of learners and educators is prohibited. Equally, no learner or educator is compelled to disclose his or her status to the school or employer.

One of the tangible outcomes of the Policy is the integration of life-skills, sexuality and HIV/AIDS education into the school curriculum. This is in line with Curriculum 2005, implementing Outcome Based Education (Department of Education, 1997) which includes, life-skills, sexuality and HIV/AIDS as one of the eight learning areas of Life Orientation. Moreover, in November 1999 the National Inter-Ministerial Committee received funding from the European Union to the amount of R450 million over a three year period: R75 million in 2000/2001; R125 million in 2001/2002 and R250 million in 2002/2003 in order to put a plan in place for children infected and affected by the epidemic. On 2 December 1999 the National Ministerial Committee decided to form a Social Cluster with the Department of Education, Department of Health and Department of Social development in order to develop an integrated strategy to address the epidemic and its effect among children and youth. The responsibility of the Department of Education according to the National Integrated Plan for children affected and infected with HIV/AIDS (Departments of Education, Health and Social Development, 2000) is to implement the life-skills, sexuality and HIV/AIDS education programmes at schools in order to prevent new infections among the youth. Clearly then, life-skills and HIV/AIDS education implemented at schools is a tangible outcome of both the Policy and the National Integrated Plan (NIP). The NIP project is based on the premise that it "intends to augment current provincial activities and not replace current initiatives" (Departments of Education, Health and Social Development, 2000:3). In other words, the NIP is meant to strengthen the implementation of the life-skills, sexuality and HIV/AIDS education programme which forms part of the Life Orientation Programme of Curriculum 2005.

Further scrutiny of both the Policy and the NIP document reveal an important missing element, that of a lack of monitoring and evaluation system. This study was based on the premise that Provincial HIV/AIDS programmes and policies should be monitored and evaluated on an on-going basis in order to render the effectiveness of implementation at "grassroots" level truly effective. The findings of this study confirm the argument put forth by writers in the field of policy analysis such as Levin (1997), Jansson (1999); Ramanathan and Link (1999) De Beer and Swanepoel (2002), Sewpaul and Raniga (2005) who maintain that a disparity exists between policy goals and the resources and mechanisms that is required to operationalise policy. The preliminary study's findings demonstrated that social work intervention in schools can bridge the gap between policy awareness and implementation. By adopting an action research strategy stakeholders such as an HIV positive woman, health professionals and social workers collaborating with several NGOs co- 
operated in a long term developmental process to produce results in line with the National HIV/AIDS School Policy (Sewpaul \& Raniga, 2005).

Upon close scrutiny of the Policy, it is evident that there is a contradictory statement made in the document. The Policy indicates (Department of Education, 1999:2) that the Ministry of Education is committed to provide leadership to implement the HIV/AIDS Policy and that "...this policy seeks to contribute towards promoting effective prevention and care within the context of the public education system" (Department of Education, 1999:2). In point 2.11 of the Policy it is then stipulated that this national policy is intended as broad principles only and that the operational responsibility of the Policy lies with the school governing bodies of schools. Such contradictory policy goals imply a shift of responsibility of government in the provision of key social services such as education, health, welfare and housing to the private sector and communities. Within a neoliberal, capitalist ideology substantiates the non-interventionist role of government in the provision of social services. Writers such as Bond (2005), Sewpaul (2004, 2005), Desai (2002), have aptly criticised the GEAR policy as being an inconsistent economic strategy to promote growth and employment and that South Africa's problems cannot be effectively addressed by the kind of neo-liberal, free market policies to which the IMF and the World Bank adhere.

Similarly, the NIP document advocates for a "district based approach" to be followed (Department of Social Development, Health and Education, 2000:3). This approach entails the mobilisation of community resources in order to address the epidemic at a mezzo level. This shift of responsibility for the care of learners infected and or affected by HIV/AIDS to households and communities is problematic. This approach, enshrined within a neoliberal, capitalist ideology, reduces the cost of care to government, while it increases the emotional burden and financial strain of families and communities. Research conducted by Simpson and Raniga (2004) on the effects of HIV/AIDS in four informal settlements in the eThekwini region revealed that the problem of HIV/AIDS is straining the already strained resources and coping mechanisms of people in poverty stricken communities.

Writing in the context of rural schools, Sathiparsad and Taylor (2005) highlight the complex relationship between structural problems such as poverty, socio-economic conditions and family problems and its link to learners' performance at schools. It is disappointing to note that both the Policy and the NIP document do not take cognizance of socio-structural factors such as poverty, inequality and social exclusion and the profound effect that these factors have on the school system as well as on learners' and their families either infected and or affected by the virus. It is here that I agree with Sewpaul's (2005:310) critical analysis of the South African draft Family Policy, where she contends that policies need to take cognizance of the way neoliberal capitalism and market-induced inequality and factors such as race, class and gender intersect to influence people's lives at a micro level and in this case at the mezzo (school and household) level.

\section{Section Two: Analysis and discussion of empirical results}

\section{Increased awareness and implementation of the Policy}

Overall, 68 schools in the sample indicated that they were aware of the policy and six schools were unaware of the National HIV/AIDS School Policy. A total of six schools mainly in the rural locality revealed that they were unaware of the Policy. In the preliminary study undertaken in 2001, telephonic interviews with principals from 18 secondary schools in Phoenix (North of Durban in KwaZulu-Natal) unanimously indicated that they had little awareness of the policy and limited implementation of HIV/AIDS awareness programmes in schools (Sewpaul \& Raniga, 2005). In this extended study, the findings reveal substantial increase in the awareness of the 
National HIV/AIDS School Policy. This finding may be attributed to two key factors. Firstly, the time frame since the implementation of the Policy in August 1999 to the present reflected that it takes time for policies developed at national (macro) level to filter down to the school (mezzo) level. Second, an interview with the national co-ordinator of the Life-skills, HIV/AIDS programme confirmed that the Department of Education has actively marketed the Policy at schools in the past two years. However, it is important to consider whether schools moved beyond awareness of the Policy to implementation. Interestingly, Karlsson (2000) stated that although the Department of Education (DoE) actively marketed the HIV/AIDS Policy to schools throughout South Africa, very few implementation initiatives were evident in schools. This point is illustrated further in the discussion following Figure 1.

FIGURE 1

IMPLEMENTATION OF THE NATIONAL HIV/AIDS SCHOOL POLICY BY LOCATION

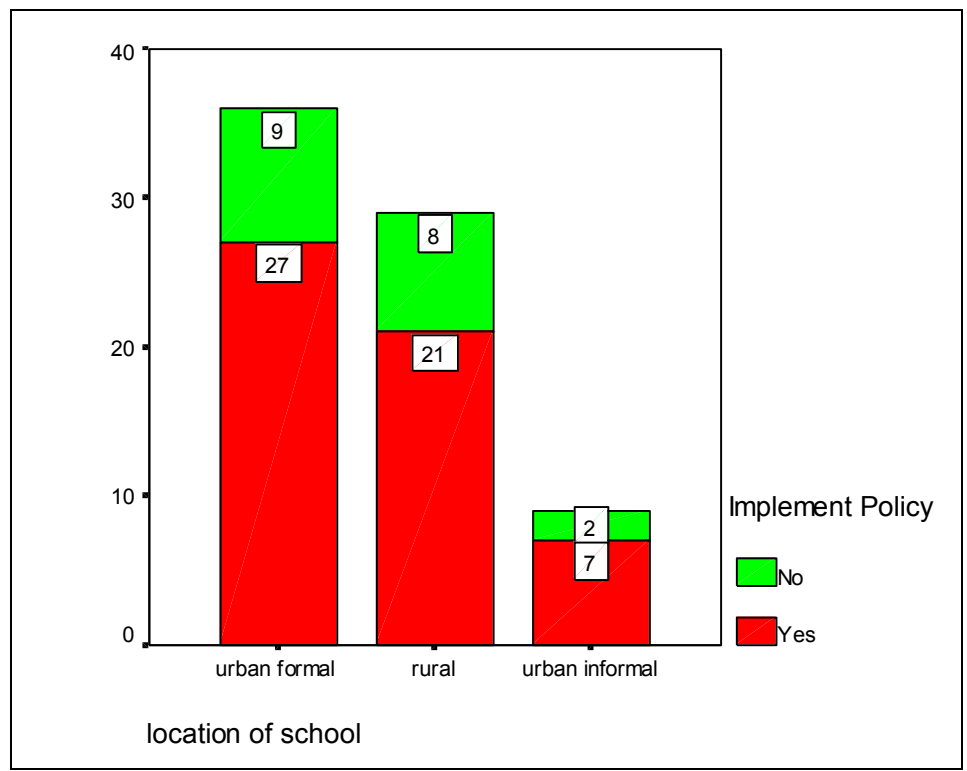

Figure 1 illustrates that 55 schools $(74 \%)$ in the sample were implementing the Policy while a total of 19 schools (26\% of the sample) were not implementing the Policy. Given the extent of the problem of HIV/AIDS and the active marketing of the policy to schools by the Department of Education, it is discouraging that a quarter of the schools in this sample were not implementing the Policy. This is contrary to the "Tirisano" (Department of Education, 2000a, 2000b, 2000c) document's emphasis that policy implementation is fundamental to central government. These findings need to be viewed in relation to the challenges experienced by schools in operationalising the Policy.

\section{The challenges experienced by schools in operationalising the National Life-skills and HIV/AIDS school policy}

The findings from the preliminary study (Sewpaul \& Raniga, 2005) confirmed that the majority of the schools in the North of Durban (Phoenix) region in KwaZulu-Natal experienced problems with the practical implementation of this Policy. This finding concurs with the findings of the 
quantitative audit undertaken in the 74 schools. Figure 2 provides further insight into the problems experienced by schools in the operationalisation of the Policy.

FIGURE 2

PROBLEMS EXPERIENCED BY SCHOOLS (BY LOCATION) IN OPERATIONALISING THE POLICY

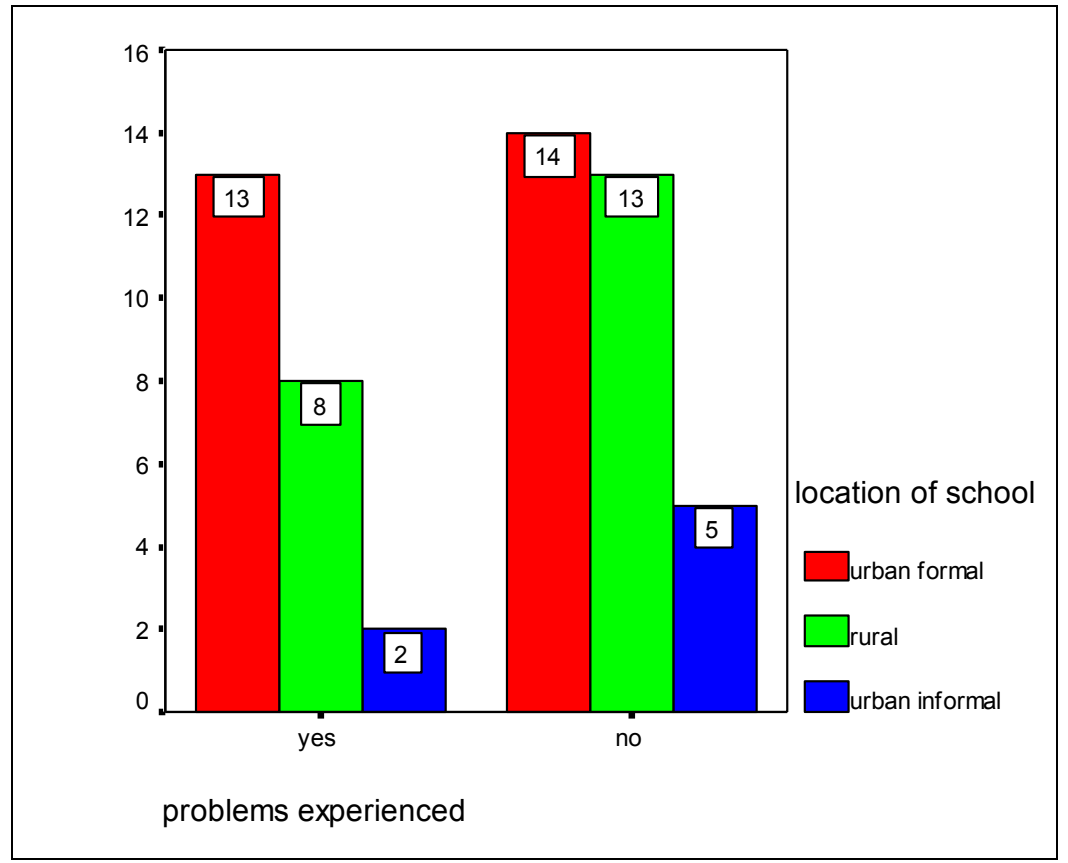

Figure 2 reveals that of the total 55 schools implementing the Policy (Department of Education, 1999), 23 schools indicated that they experienced problems with implementation. There were several reasons given by the principals with regard to problems experienced. First, the training organized by the Department of Education for the life-skills, HIV/AIDS programme was inadequate and that there was very little support and monitoring done after the training workshops, which were conducted in 2002. Second, one principal from a rural school stated: "we need enough space to keep material and teach the life-skills, HIV/AIDS programme". Third, another principal spoke about insufficient support mechanisms to assist learners and educators who are either affected and/or infected by the disease. Fourth, a principal from an urban formal school asserted: "it is beyond the school to deal with the problem of HIV/AIDS and we need support services from government". This finding is similar to the findings of the preliminary study (Sewpaul \& Raniga, 2005), where principals complained about the lack of institutional capacity (human resource, time, role of the Department of Education, time and finance) in schools to deal with HIV/AIDS. This finding corroborates with the Education Policy Unit's (in KwaZulu-Natal) 1998 survey of 80 schools across the country, which found that the majority of schools received no guidance from education departments on how to proceed with the integration of policies (Karlsson, 2000).

Some principals spoke about networking with other non governmental organisations (NGOs) and the "Love Life" programme (a national initiative intended to promote life and sexuality education) in order to supplement the life-skills, HIV/AIDS education programme taught at the school. The findings from this extended study is similar to the pilot study, where one of the principals 
interviewed in the pilot study, reflecting the general views of other principals commented: "educators are overloaded and dealing with HIV/AIDS problems in the school context needs a specialist person such as a social worker to provide supportive and counselling services to learners as HIV/AIDS is a reality and many learners are emotionally affected by parents that are terminally ill and dying". Some principals from the urban formal areas spoke about "informal relations" that were developed with community social workers in order to provide supportive services to learners currently affected by the disease. Similar sentiments were shared when one group of learners from the rural community who participated in Phase Two of this study commented: "we need social workers to provide counselling and support to us with regard to HIV/AIDS". Clearly the findings here support the findings of the preliminary research conducted by Sewpaul \& Raniga (2005) and Sathiparsad and Taylor (2005) in which both studies advocate for social work intervention in schools.

\section{THE DISPARITY THAT EXISTS BETWEEN INSTITUTIONAL CAPACITY OF URBAN SCHOOLS AS COMPARED TO RURAL SCHOOLS IN IMPLE- MENTING THE POLICY}

One of the tangible objectives of the School-based Policy on HIV/AIDS (Department of Education, 1999) is safety in the school environment. Section seven of the Policy outlines the universal precautions that schools should follow in order to ensure safety in the school environment. It was therefore important to find out the extent to which schools were adhering to these universal precautionary measures. One of the universal precautionary measures outlined in the Policy (Department of Education, 1999) stipulates that "all wounds, sores, breaks in skin, skin grazes and lesions must be washed with running water for 3 minutes".

It was positive to note that 59 schools in the sample were adhering to this principle. However, what is of concern is that $12(41 \%)$ of the total of 29 rural schools in the sample did not have access to running water and were not adhering to this principle. One principal indicated: "we don't have running water in this school so how can we fulfil what is stated in the Policy?" "This is a luxury at our schools", stated one principal from a rural school. Overall the frustration experienced by principals in the rural schools is reflected in the following comment of one principal who stated: "the Department of Education should concentrate on improving resources and facilities in our schools, we don't even have proper water and toilets for learners". There is a definite relationship between maintaining safety in the school and access to basic services such as running water. Even though the Department of Education has committed to improving facilities and infrastructure in schools (especially rural) but delivery of such promises is slow and adversely affects the overall functioning at schools. It is of concern to note that twelve years have elapsed since entering South Africa's "new" democracy, yet the findings reflect huge disparities in resource allocations between urban and rural schools. The National school register of needs survey conducted in 2000 (on website http://www.sadtu.org.za/pub.htm.) revealed that $28 \%$ of schools in the country, which translates to $16.6 \%$ (1.9 million) learners, had no access to water and sanitation facilities. Moreover, $15 \%$ of the toilets in rural areas, at the time of this survey were not working. In relation to this, De Beer and Swanepoel (2002) contend that policies that ignore the complex dynamics between urban and rural areas have always been beneficial to the urban areas at the detriment of rural areas. These writers add that: “...without a national commitment reflected in national policy there is no basis for development and development will therefore at best be haphazard and ad hoc". Unless the disparity between access to basic services is addressed in rural schools, the implementation of the Policy and the life-skills, HIV/AIDS education programme in schools will be problematic. 
The findings thus reveal that maintaining safety and adhering to universal precautions is closely linked with the institutional capacity within schools (access to basic services and resources). This theme is elaborated in the discussion that follows.

\section{THE LACK OF INSTITUTIONAL CAPACITY AT SCHOOL LEVEL TO DEAL WITH THE PROBLEM OF HIV/AIDS}

A key premise of the Policy is that "...it is imperative that each school must have a planned strategy to cope with the epidemic" (Department of Education, 1999:4). As such an institutional system recommended by the National HIV/AIDS School Policy is that every school should establish "its own Health Advisory Committee" in order to develop an appropriate implementation plan on HIV/AIDS for the school. The Health Advisory Committee (HAC), drawing on expertise from within the school (learners, parents, educators and governing body members) and from the wider community (nurses, doctors, social workers, psychologists etc.) would be better able to enhance care and support for those learners, families and educators who are infected and or affected by HIV/AIDS.

A core purpose of this committee is to put together a comprehensive HIV/AIDS programme to be implemented in the school context (Department of Education, 1999). In order to enhance care and support at the mezzo level (family, school and community level) it is important that family and community strengths are identified and built upon to maximise the potential of each community to care for the children affected and infected by HIV/AIDS. Seventeen of the eighteen principals interviewed in the preliminary study indicated that they did not have a Health Advisory Committee in place (Sewpaul \& Raniga, 2005). Figure 4 provides insight into the disparity that continues to exist between policy goals and the resources and mechanisms that is required to operationalise the Policy for this extended study.

FIGURE 3

\section{INSTITUTIONAL IMPLEMENTATION OF THE NATIONAL HIV/AIDS SCHOOL POLICY}

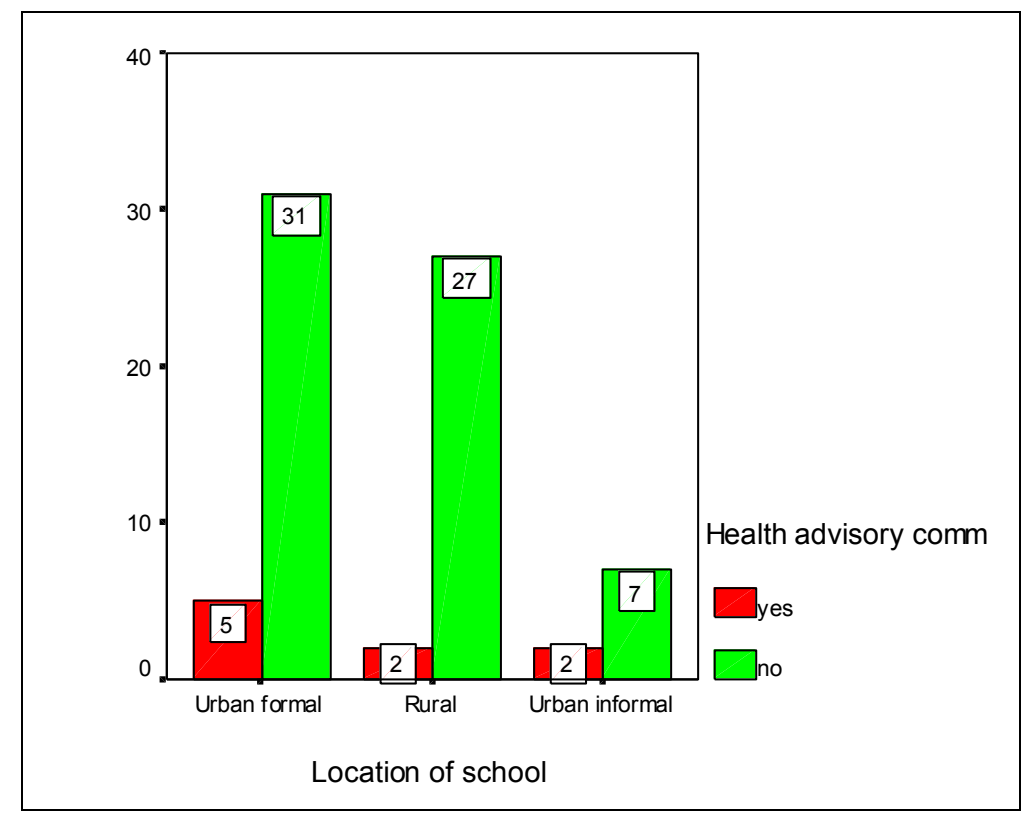


The above findings of the study show that nine of the 74 schools ( $12 \%$ of the sample) had established the Health advisory committee. Sixty five schools of which 31 were mainly within the urban formal area did not establish the Health Advisory Committee, implying that the institutional support mechanisms were compromised. An interview with the national co-ordinator of the NIP at the Department of Education confirmed that: "it is a major gap that schools don't have the HAC. For the provision of care and support to learners infected and affected by HIV/AIDS, you need the establishment of the HAC within the school context". She added that the current human resource capacity to deal with the problems of HIV/AIDS in the school context is grossly inadequate and she supported the recommendations for social work services in schools. Research conducted by Khoza (2002), Taylor et al. (2002) and the preliminary study conducted by Sewpaul and Raniga (2005) confirm that there is a lack of institutional capacity at school level to deal with the problem of HIV/AIDS. Unless the present institutional capacity (human resources, regular training, proper district based support systems, provision of basic services to rural areas) is strengthened by the Department of Education, the life-skills education programme targeted at youth within the formal education sector will remain a challenge.

\section{CONCLUSION}

The ultimate objective of all HIV/AIDS policies should be to strengthen central, provincial, local government and civil society responses to the HIV/AIDS epidemic. The findings of the study illustrate the disparity between policy ideals and policy implementation in the arena of HIV/AIDS. The findings of the quantitative audit show that even though there has been a significant increase in the awareness of the National HIV/AIDS School Policy across different school locations within the eThekwini region, schools experience problems with the implementation of the Policy and the life-skills, HIV/AIDS education programme. This is primarily due to the lack of institutional capacity (lack of access to basic services such as water, lack of provision of support and material from the Department of Education) at schools to deal with the problem of HIV/AIDS. Additionally the findings reveal that a disparity exists between the institutional capacity of urban schools as compared to rural schools with regard to the implementation of the National HIV/AIDS School Policy and the life-skills, HIV/AIDS education programme. The KwaZulu-Natal Department of Education needs to urgently improve access to basic services such as water and sanitation in rural schools in the eThekwini region. Additionally it is imperative that officials employed by the Department of Education provide ongoing training, support and guidance to life orientation educators. Of particular importance is the finding that only 9 schools of the total sample of 74 had established a Health advisory committee. The finding of the preliminary study confirmed that it is imperative for every school to establish Health advisory committees as an institutional support mechanism to manage HIV/AIDS problems in the school context (Sewpaul \& Raniga, 2005).

Additionally there is an urgent need for collaborative partnerships between the Department of Social Development and Education in order to develop comprehensive intervention strategies to ensure that necessary supportive services are given to learners and their families who are affected and infected with HIV/AIDS.

The National HIV/AIDS School Policy (Department of Education, 1999) and the National Integrated Plan for children infected and affected by HIV/AIDS (Departments of Social Development, Health and Education, 2000) both emphasize the need to create an enabling environment in order to curb infection rates among young people. I have argued that unless such policies take cognizance of the structural problems such as poverty, inequality and social exclusion and the impact of these factors on schools, the objectives to create an enabling environment to deal 
with HIV/AIDS related problems at schools will remain a challenge. The findings of this extended study support the findings of the preliminary study which confirmed that "social work with its small group facilitation skills, its understanding of human and cultural diversity, its ability to connect micro, mezzo and macro levels of assessment and intervention, its emphasis on values, knowledge and skills that social workers receive in the areas of human sexuality and HIV/AIDS, render social work a suitable discipline to implement HIV/AIDS and management programmes in schools" (Sewpaul \& Raniga, 2005:277).

\section{REFERENCES}

ABDOOL KARIM .S.S. \& ABDOOL KARIM, Q. (eds) 2005. HIV/AIDS in South Africa. New York: Cambridge University Press.

BADCOCK-WALTERS, P. 2002. On education. In: GOW, J. \& DESMOND, C (eds) Impacts and interventions - the HIV/AIDS epidemic and the children of South Africa. Pietermaritzburg: University of Natal Press.

BOND, P. 2005. A civil society reader on the new partnership for Africa's development: Fanon's warning. Eritrea: Africa World Press, Inc.

CAMPBELL, C. 2003. "Letting them die" How HIV/AIDS prevention programmes often fail. Cape Town: Juta.

DE BEER, F. \& SWANEPOEL H. 2002. Introduction to development studies. Southern Africa: Oxford University Press.

DESAI, A 2002. We are the poors: Community struggles in post-apartheid South Africa. New York: Monthly Review Press.

DEPARTMENT OF EDUCATION 1996. Education White Paper 2: The organisation, governance and funding of schools. Government Gazette, 368 (16987). Pretoria.

DEPARTMENT OF EDUCATION 1997. Curriculum 2005: Learning for the $\mathbf{2}^{\text {st }}$ century. Pretoria.

DEPARTMENT OF EDUCATION 1999. National Policy on HIV/AIDS, for learners and educators in Public Schools, and Students and Educators in Further Education and Training Institutions, Government Gazette Notice 1926 of 1999. Pretoria.

DEPARTMENTS OF EDUCATION, HEALTH AND SOCIAL DEVELOPMENT. 2000. National Integrated Plan for children infected and affected by HIV/AIDS. Pretoria.

DEPARTMENT OF EDUCATION 2000a. Corporate plan January 2000 - December 2004. Department of Education, Pretoria.

DEPARTMENT OF EDUCATION 2000b. Implementation plan for Tirisano: January 2000 December 2004. Department of Education, Pretoria.

DEPARTMENT OF EDUCATION 2000c. Quality education for all: statement of public service commitment January 2000. Department of Education, Pretoria.

DEPARTMENT OF HEALTH 1999. Lifeskills and HIV/AIDS Education Programme. Department of Health, Pretoria.

DEPARTMENT OF HEALTH 2001. National HIV sero-prevalence of women attending public health antenatal clinics in South Africa 2000. Department of Health, Pretoria. 
GOW, J. \& DESMOND, C. (eds) 2002. Impacts and Interventions - the HIV/AIDS epidemic and the children of South Africa. Pietermaritzburg: University of Natal Press.

HARRISON, A. 2005. On young people and HIV/AIDS in South Africa: Prevalence of infection, risk factors and social context. In: ABDOOL KARIM, S.S \& ABDOOL KARIM, Q. (eds) HIV/AIDS in South Africa. New York: Cambridge University.

JANSSON, B.S. 1999. Becoming an effective policy advocate: From policy practice to social justice. Boston: Brooks/Cole Publishing Company.

KARLSSON, J. 2000. Review of Education Policy 1998-2000. Durban: Education Policy Unit, University of Natal.

KHOZA, V. 2002. Schools: Safe havens or sites of violence. Agenda, 53:75-88.

NATIONAL EDUCATION POLICY Act (No.27 of 1996). Department of Education, Pretoria.

LEVIN, P. 1997. Making social policy: The mechanism of government and politics and how to investigate them. Philadelphia: Open University Press.

MARLOW, C. 1998. Research methods for generalist social work ( $2^{\text {nd }}$ ed). Brookes/Cole Publishing Company.

RAMANATHAN, C. \& LINK, R, 1999. All or future: Principles and resources for social work practice in a global era. Wadsworth: Brookes/Cole,

SATHIPARSAD, R. \& TAYLOR, M. 2005. Towards social work intervention in rural schools: Perspectives of educators. Social Work/Maatskaplike Werk, 41(3):265-275.

SEWPAUL, V. \& RANIGA, T. 2005. Producing results: Researching social work interventions on HIV/AIDS in the context of the school. In: ADAMS, R., DOMINELLI, L. \& PAYNE, M. Social work futures: Crossing boundaries, transforming practice. Palgrave: Macmillan.

SEWPAUL, V. 2004. Globalisation, African governance and the new partnership for Africa's development. In: TIONG, N.T. \& ROWLANDS, A. (eds) Social work around the world. Berne: IFSW Press.

SEWPAUL V. 2005. Structural Social Justice Approach To Family Policy: Critique of the Draft South African Family Policy. Social Work/Maatskaplike Werk, 41(4):310-322.

SIMPSON, B. 2001. Social work in informal settlements in the Durban Metro Region. Durban: University of Natal. (PhD dissertation)

SIMPSON, B. \& RANIGA, T. 2004. Co-housing as a possible housing option for children affected by HIV/AIDS: evidence from informal settlements. Urban Forum, 15(4):365-379.

STATISTICS SOUTH AFRICA. 1998. Census 1996. Available: http://www.statsa.gov.za/census 2001/census96/HTML/default.htm [Accessed: 16 July 2005].

STATISTICS SOUTH AFRICA. 2003. Census 2001. Available: http://www.statssa.gov.za/ census01/html [Accessed: 6 March 2006].

TAYLOR, M., DLAMINI, S., KAGORO, H., JINABHAI, C., SATHIPARSAD, R. \& DE VRIES, H. 2002. Self-reported risk behaviour of learners at rural KwaZulu-Natal high schools. Agenda, (53):69-74. 
TERRE BLANCHE, M. \& DURRHEIM, K. (eds) 1999. Research in practice: Applied methods for the social sciences. Cape Town: University of Cape Town Press.

THE NATIONAL SCHOOL REGISTER OF NEEDS 2000 SURVEY. Available: http://www.sadtu.org.za/pub.htm [Accessed: 4 April 2006].

VAN RENSBURG, D., FRIEDMAN, I., NGWENA, C., PELSER, A., STEYN, F., BOOYSEN, F., ADENDORFF, E. 2002. Strengthening local government and civic responses to the HIV/AIDS epidemic in South Africa. Centre for Health Systems Research and Development.

Ms Tanusha Raniga is a Lecturer in the School of Social Work and Community Development, University of KwaZulu-Natal, South Africa. 